398. 従来の増感紙・フイルム系の非対称性について

\title{
The asymmetry of conventional screen/film system
}

\author{
近畿大学医学部附属病院 \\ ○岡田弘治福井豊橋場久幸西松和彦 \\ (Hiroharu Okada) (Yutaka Fukui) (Hisayuki Hashiba) (Kazuhiko Nishimatsu) \\ 国立療湌所宇多野病院 \\ 若松芓司
}

(Takashi Wakamatsu)

【目的】従来のようなフイルムの雨面に同一の乳刘が塗布された、裏表の区別のない、い わゆる対称なフイルムを用いた場合に、組合わせる増感紙や管電压の変化における非対 称性について検討を行う。

【方法】(1)非対称な特性が効果的に現われることを考虑し、クロスオーバの殆どない対称 なフイルム、Kodak MinR-T(以下,*と記す)を用いて、前面と後面が同一なシステム(Lanex Fine/*Fine)と、前面と後面が異なるシステム(Fine//Medium)の増感紙の組合せを用いた。 管電圧 $50,60,80 \mathrm{kV}$ ，お゙よひ $80 \mathrm{kV} 20 \mathrm{mmAl}$ られたべき数を用いて、Fine/*Fine系とFine/Medium系に対してセンシメトリーを行い、 H \& D曲線からグラディエント曲線を求めた。(2)スリット法を用いて、各系のフイルム の前面・後面のついて M T F を求め、グラティエント結合法によって濃度域に対する T F を得た。(3)管電圧に対するM T F の比較を、Fine/*Medium系の場合について行った。 【結果と考察】(1)前面と後面とが同一の增感紙の場合、管電圧の上昇に対して、グラディ エントは高くなり、異なる場合では低くなった。管電圧が上昇すると、前面のH\&D曲線 は高露光側に、後面のH\&D曲線は低露光側に各ヶシフトする。增感紙が異なる場合、後 面のH\&D曲線は低露光側にあり、管電圧の上昇と共に露光量の差が大きくなり、グラテ ィエントは低くなる。(2)前面と後面が同一の增感紙の場合、濃度に対してMT F は、從 来のように変わらない。これは,グラディント結合法の式において,分母・分子でグデ ィエントが消去されるためである。增感紙が異なる場合の M T F は变化している。(3)測 定結果より,濃度 1.0 ,および1.8の場合においても管電圧の上昇に対して M T F は、変化し なかった。K特性 X線の影響を含め再確認する必要がある。以上の結果は、従来のク口 スオーバを有する対称なフイルムを用いた場合の非対称性の存在を示唆している。

Lanex MEDIUM/MinR-T/MEDIUM Lanex FINE/MinR-T/MEDIUM
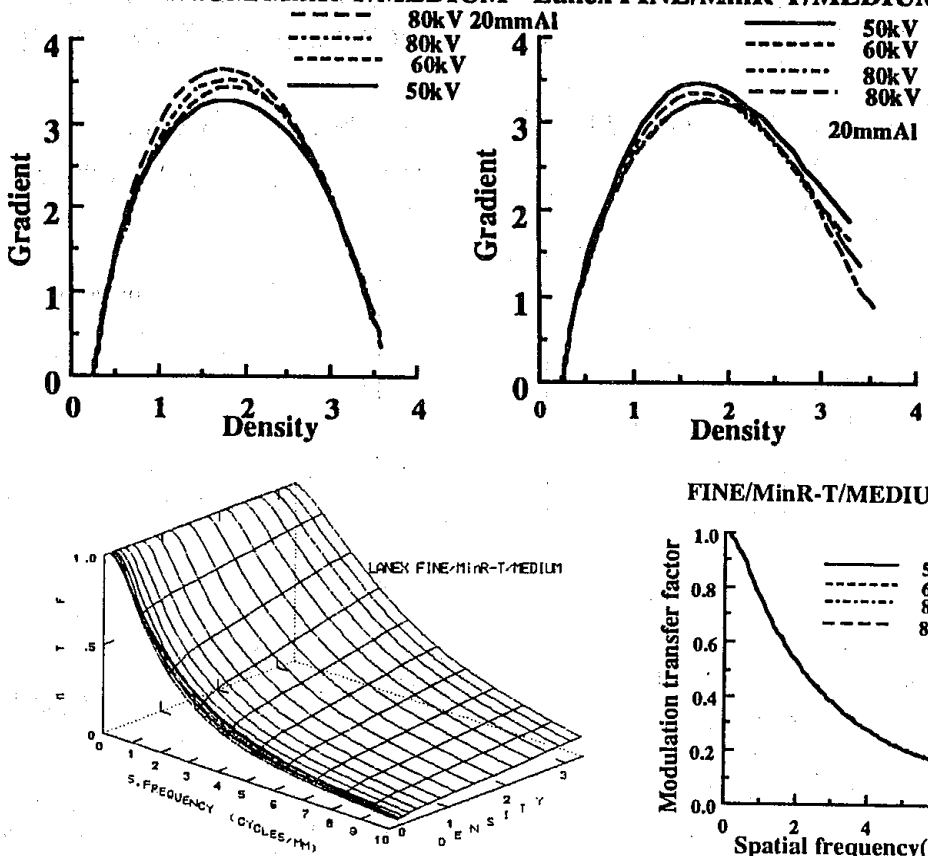

FINE/MinR-T/MEDIUM( $D=1.0)$

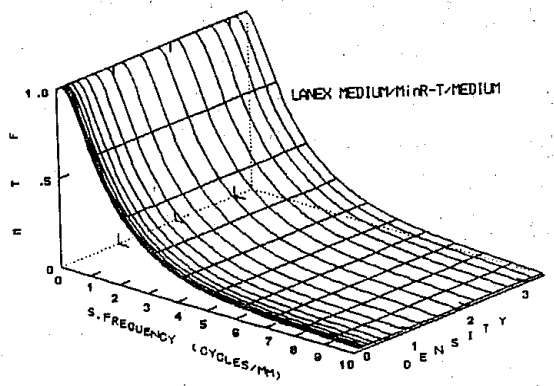

FINE/MinR-T/MEDIUM( $D=1.8)$
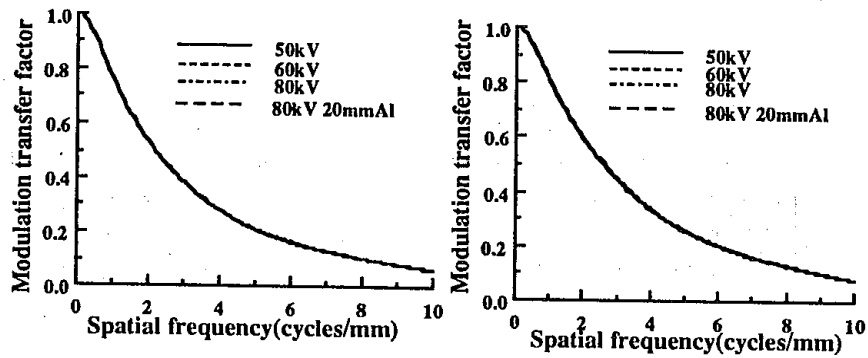